\title{
A molecular and phenotypic study of Vibrio cholerae in Iran
}

\author{
M. POURSHAFIE, F. GRIMONT*, S. KOHESTANI and P. A. D. GRIMONT* \\ Department of Bacteriology, Pasteur Institute of Iran, Tehran, Iran and *Institut Pasteur, Unite des \\ Enterobacteries, Unite INSERM 389, 75724, Paris Cedex 15, France
}

\begin{abstract}
Vibrio cholerae is again the subject of attention on account of the current increase in the world-wide incidence of cholera. In this study, 200 clinical isolates of $V$. cholerae serotypes 01 and non-O1, non-O139, were collected from different provinces in Iran. The isolates were subjected to biochemical analysis, antibiogram, PCR of toxin genes, plasmid profile, ribotyping and pulsed-field gel electrophoresis (PFGE). The analysis of plasmid content showed that $33-96 \%$ of $V$. cholerae isolated from different provinces carry a large plasmid. PCR analysis of $V$. cholerae $O 1$ showed that the genes encoding cholera toxin (ctx), toxin co-regulated pilus (tcp), accessory cholera enterotoxin (ace) and zonula occludens toxin (zot) were present in $55-97 \%$ of isolates in different provinces. Restriction fragment length polymorphism (RFLP) of BglI-digested DNA probed with five oligonucleotides revealed three different ribotype patterns in isolates of $V$. cholerae O1. The ribotype pattern B21 of $V$. cholerae $01 \mathrm{El}$ Tor was found to be the predominant pattern in the isolates studied. $V$. cholerae non-O1, non-O139 isolates showed a single ribotype pattern. PFGE analysis also showed 10 different patterns amongst the isolates, 9 of which were in $V$. cholerae $O 1$. Overall, the analysis of polymorphism of ribotypes and PFGE patterns of the isolates showed that the provinces in Iran were affected by a limited number of clones of $V$. cholerae 01 and non-O1, non-O139 strains.
\end{abstract}

\section{Introduction}

Seven widespread pandemics of cholera have been recorded in which Vibrio cholerae O1 biotype El Tor has spread to many Asian countries since its emergence in Indonesia in 1961 [1].

Studies of the molecular evolution of strains of $V$. cholerae isolated in Peru [2, 3], India [4] and Thailand [5] have shown that $V$. cholerae $\mathrm{O} 1$ undergoes genetic changes relatively frequently. $V$. cholerae serotype O139 emerged in India [6] and spread to countries such as Thailand [7] and Pakistan [8], demonstrating the ability of $V$. cholerae to mutate and spread rapidly. Furthermore, horizontal gene transfer between different serotypes of $V$. cholerae is believed to have resulted in new variants such as $V$. cholerae $\mathrm{O} 139$, which is considered to be the result of gene transfer between $\mathrm{O} 1$ and non-O1 serogroups [9]. Therefore, the study of genetic changes of $V$. cholerae is important in under-

Received 22 June 2001; revised version accepted 29 Nov. 2001.

Corresponding author: Dr M. Pourshafie (e-mail: pour62@ yahoo.com). standing the epidemiology and evolution of the cholera bacteria.

Despite the importance of $V$. cholerae as a cause of diarrhoea in Iran, there is little published information on cholera in that country. This study reports the molecular characterisation of $V$. cholerae $\mathrm{O} 1$ biotype El Tor as well as non-O1, non-O139 isolates from infected patients in different provinces in Iran during 19992000. Restriction fragment length polymorphism (RFLP) of the 16S and 23S rRNA genes (ribotyping), pulsed-field gel electrophoresis (PFGE), analysis of plasmid content and PCR of the toxin genes were all used for genotypic characterisation of the isolates. The antibiotic susceptibility patterns of the isolates were also examined, because of increasing reports of antibiotic resistance in strains of $V$. cholerae $\mathrm{O} 1$.

\section{Materials and methods}

\section{Specimen collection}

In all, 200 isolates of $V$ cholerae were obtained in 1999 and 2000 from patients suspected of having cholera. The samples were collected in different provinces in 
Iran, including Tehran, Sistasan and Baluchastan, Kerman, Kermanshah, Kuzhastan and Kashan provinces. The specimens were collected on sterile swabs, which were then placed in Cary-Blair transport medium [10]. Alkaline peptone water was used for the enrichment of $V$. cholerae, which was then isolated on thiosulphate-citrate-bile salt-sucrose (TCBS) agar (Sanofi Diagnostic Pasteur, Marnes-La-Coquette, France).

\section{Biochemical analysis and serotyping}

Biochemical identification and serotyping were performed by standard procedures [11]. Isolates were serotyped with monospecific sera purchased from Eurobio (Les Ulis, France). The isolates were identified as either $V$. cholerae $\mathrm{O} 1$ biotype El Tor with serotypes of Ogawa, Inaba, or non-agglutinable with $\mathrm{O} 1$ and O139 serotypes recognised as non-O1, non-O139 $V$. cholerae.

\section{Antibiotic susceptibility testing}

The antibiotic susceptibilities of isolates were tested by the standard disk technique [12]. The following antibiotic disks were used (mg): doxycycline (30), chloramphenicol (30), trimethoprim/sulphamethoxazole (25), gentamicin (10), tetracycline (30), erythromycin (15), oxytetracycline (30), ciprofloxacin (5), furazolidone (100) and streptomycin (10). The antibiotic disks were purchased from Difco Laboratories (Detroit, MI, USA).

\section{Isolation of plasmid DNA}

Plasmids were isolated by the method of Kado and Liu [13], with some modifications. Briefly, cells were grown in $3 \mathrm{ml}$ of TCS broth overnight to an $\mathrm{OD}_{600}$ of 0.8 and were then incubated for $30 \mathrm{~min}$ at $56^{\circ} \mathrm{C}$ at $\mathrm{pH} 12$ for lysis. After lysis, phenol:chloroform:isoamylalchohol (25:24:1) was added and the samples were mixed. The samples were examined by electrophoresis for the presence of plasmids in the supernates.

\section{Gene detection by PCR}

DNA was extracted with the Wizard genomic DNA purification kit (Promega, Madison, WI, USA). PCR was performed in a reaction mixture containing sterile water $35 \mathrm{ml}, 10 \times$ Taq polymerase buffer $5 \mathrm{ml}, 200 \mathrm{mM}$ deoxynucleotide phosphate (dNTP), Taq DNA polymerase (Amersham Pharmacia Biotech, Uppsala, Sweden) 2.5 units, DNA template $1 \mathrm{ml}$ and 50 pmol of each primer. The primers were for cholera toxin $(\operatorname{ctx} \mathrm{A})$, accessory cholera enterotoxin (ace), zonula occludens toxin (zot) and toxin co-regulated pilus (tcpA) (Table 1) [14-17], which were synthesised and purified by Genset (Paris, France). The cycling conditions were as follows: pre-incubation at $94^{\circ} \mathrm{C}$ for $5 \mathrm{~min}, 35$ cycles of $1 \mathrm{~min}$ at $94^{\circ} \mathrm{C}$ for denaturation, $1 \mathrm{~min}$ at $64^{\circ} \mathrm{C}$ for annealing, $2 \mathrm{~min}$ at $72^{\circ} \mathrm{C}$ for elongation and incubation at $72^{\circ} \mathrm{C}$ for $3 \mathrm{~min}$ for final elongation. The amplicons were electrophoresed through agarose $0.8 \%$ gel (Appligene, Illkirch, France) and then stained with ethidium bromide. A negative control (reaction mixture without template) and a toxin-positive control ( $V$. cholerae O1 strain 0395) were included in each run [18].

\section{Ribotyping}

The extracted DNA was cleaved by restriction endonuclease Bgll (Life Technologies, Cergy Pontoise, France) $20 \mathrm{U} / \mathrm{ml}$ at $37^{\circ} \mathrm{C}$ for at least $4 \mathrm{~h}$. The fragments were separated by electrophoresis in an agarose $0.8 \%$ gel (Appligene) in Tris-borate buffer ( $89 \mathrm{~mm}$ Tris, $89 \mathrm{~mm}$ borate, $2 \mathrm{~mm}$ EDTA, $\mathrm{pH}$ 8.3) for $16 \mathrm{~h}$ at $1.5 \mathrm{~V} / \mathrm{cm}$. The DNA fragments were then transferred to nylon membranes (Hybond $\mathrm{N}+$, USB Life Science) by an alkali blotting procedure with a vacuum blotter (Amersham Pharmacia Biotech). Hybridisation was performed with a probe labelled with digoxigenin-11-dUTP (DIG). The membranes were then visualised by the addition of alkaline phosphatase-conjugated anti-digoxigenin antibody (anti-DIGAP; Boehringer Mannheim GmbH, Germany) and 5bromo-4-chloro-3-indolyl phosphate substrate and nitroblue tetrazolium (Research Organics, Cleveland, $\mathrm{OH}$, USA) [19]. Digitisation and interpretation of patterns were done with programs in the Taxotron package (Taxolab, Institut Pasteur, Paris). The membranes were first scanned and the images searched for bands by RestrictoScan. RestrictoTyper was used to interpolate the fragment sizes from migration data $[18,20,21]$. DNA from Citrobacter koseri strain CIP 105177 (Collection de l'Institut Pasteur) was cleaved by MluI

Table 1. Oligonucleotides used for PCR amplification of the toxin genes

\begin{tabular}{|c|c|c|c|}
\hline Gene & Oligonucleotide & Sequence & Reference \\
\hline \multirow[t]{2}{*}{$\operatorname{ctx} \mathrm{A}$} & ctx I & 5'-CGG GCA GAT TCT AGA CCT CCT G-3' & 16 \\
\hline & $\operatorname{ctx} 2$ & 5'-CGATGATCT TGG AGC ATT CCC AC-3' & \\
\hline \multirow[t]{2}{*}{ ace } & ace 1 & 5'-TAA GGA TGT GCT TAT GAT GGA CAC CC-3' & 15 \\
\hline & ace2 & 5'-CGT GAT GAATAA AGATAC TCATAG 3' & \\
\hline \multirow[t]{2}{*}{ zot } & zotl & 5'-TGG CTT CGT CTG CTG CCG GCG ATT-3' & 17 \\
\hline & zot2 & 5'-CAC TTC TAC CCA CAG CGC TTG CGC-3' & \\
\hline$t c p \mathrm{~A}$ & $\begin{array}{l}\operatorname{tcp} 525 \\
\operatorname{tcn} 568\end{array}$ & 5'-AAA GAG CTC GAT CTC CAC TCC GGA AATA-3' & 14 \\
\hline
\end{tabular}


restriction endonuclease (Amersham Pharmacia Biotech) and the fragments were then used as the molecular size standards.

\section{PFGE}

$V$. cholerae $\mathrm{O} 1$ isolates were subjected to PFGE as described previously [22, 23]. Briefly, bacterial cells were embedded in low melting-point agarose (BioRad Laboratories, Richmond, CA, USA) and lysed with lysis buffer (Sarkosyl 1\% in $0.5 \mathrm{M}$ EDTA, pH 8.0, containing lysozyme and proteinase $\mathrm{K}$ ). The DNAs were then digested with $20 \mathrm{U}$ of Not I (5'-GCGGC CGC- $3^{\prime}$ ) restriction endonuclease (Amersham, Arlington Heights, IL, USA) at $37^{\circ} \mathrm{C}$. PFGE was performed with an agarose $1 \%$ gel in Tris-borate-EDTA buffer $0.5 \%$ with a CHEF-DR II system (BioRad) under the following conditions: $6 \mathrm{~V} / \mathrm{cm}$ at $14^{\circ} \mathrm{C}$ for $22 \mathrm{~h}$ at a field angle of $120^{\circ}$. The electrophoresis was performed with switch times of $15-25 \mathrm{~s}$ for $3 \mathrm{~h}$ and $8-25 \mathrm{~s}$ for $19 \mathrm{~h}$ [5]. The DNA size standard was a $\lambda$ ladder consisting of concatemers starting at $48.5 \mathrm{~kb}$ (Biolabs, Beverly, MA, USA).

\section{Results}

\section{Bacterial specimens}

Table 2 shows the distribution of $V$. cholerae serotypes isolated from different provinces; 171 (86\%) of the isolates were identified as $V$. cholerae $\mathrm{O} 1$ biotype $\mathrm{El}$ Tor. Of the serotypes that could be identified, 158 $(92 \%)$ were Ogawa and $13(8 \%)$ were Inaba. Most Inaba strains were found in the eastern province near the border with Pakistan. $V$. cholerae non-O1, nonO139 represented $29(14 \%)$ of the total isolates, most of which were found in the central province of Iran.

\section{Distribution of the amplified toxin genes}

With the specific primers, the $V$. cholerae isolates were analysed by PCR for the presence of tcp, ctx, ace and zot genes. Table 2 also shows the most and least detected amplified genes in $V$. cholerae $\mathrm{O} 1$ isolates as the following: tcp (73\% and 66\%), ctx (97\% and $81 \%)$, ace $(78 \%$ and $55 \%)$ and zot $(92 \%$ and $67 \%)$, respectively. In only one central province, Kashan, were $V$. cholerae non-O1, non-O139 strains predominant, and the PCR results showed either the absence of the toxin genes or only a few positive results.

\section{Antibiotic resistance and conjugation experiments}

Except for one province, the antibiotic resistance study showed significant resistance to trimethoprim/sulphamethoxazole and streptomycin, and to a lesser extent to furazolidone, amongst the isolates of $V$. cholerae $\mathrm{O} 1$. Except for erythromycin and streptomycin, no antibiotic resistance was found in isolates from the province of Kashan, where all of the isolates were identified as $V$. cholerae non-O1, non-O139 (Table 3).

A large plasmid of c. $100 \mathrm{~kb}$ was found in the plasmidpositive $V$. cholerae $\mathrm{O} 1$ isolates. The percentage plasmid contents of $V$. cholerae isolates from different provinces are shown in Table 3. The greatest and least percentages of plasmids in isolates from the different provinces were $96 \%$ and $33 \%$, respectively. Plasmids were conjugated between a $V$. cholerae donor and an Escherichia coli K12 recipient. In some cases the transconjugated plasmids were shown upon conjugation to pass the antibiotic resistance to the recipient. The co-transfer of trimethoprim/sulphamethoxazole and streptomycin resistance from Iranian $V$. cholerae isolates to an $E$. coli recipient was also observed, even in the absence of detectable plasmids in the isolates.

\section{Genotyping analysis}

Fig. 1 shows the ribotypes of $V$. cholerae isolates from Iran that were digested with $B g l$ I restriction endonuclease, resulting in four different restriction patterns. Lane 1 is the representative of non-O1, non-O139 $\mathrm{V}$. cholerae isolated in the province of Kashan in Iran. This pattern was representative of $29(14 \%)$ isolates of non-O1, non-O139 strains. Lane 2 was recognised as the ribotype pattern $\mathrm{B} 15$, in our database, consisting of six bands of $13.0-4.4 \mathrm{~kb} ; 12 \%$ of $V$. cholerae O1 isolates showed this pattern. Analysis of $171 \mathrm{~V}$. cholerae $\mathrm{O} 1$ isolates showed lane 3 , identified in our database as $\mathrm{B} 21$, to be the predominant ribotype pattern with $81 \%$ of the cases. This pattern contained

Table 2. Distribution of serotypes isolated in different provinces in Iran and percentage of amplified genes in the $V$. cholerae isolates

\begin{tabular}{|c|c|c|c|c|c|c|c|c|}
\hline \multirow[b]{2}{*}{ Province } & \multirow[b]{2}{*}{$\begin{array}{l}\text { Number of } \\
\text { isolates }\end{array}$} & & \multicolumn{6}{|c|}{$\begin{array}{c}\text { Percentage of isolates carrying toxin gene } \\
\text { and of serotype }\end{array}$} \\
\hline & & & tcp & $c t x$ & ace & $z o t$ & $\begin{array}{l}\text { Ogawa } \\
\text { Inaba }\end{array}$ & $\begin{array}{r}\text { non-O1, } \\
\text { non-O139 }\end{array}$ \\
\hline Tehran & 58 & 73 & 92 & 78 & 92 & 100 & 0 & 0 \\
\hline Kashan & 29 & 8 & 9 & 0 & 0 & 0 & 0 & 100 \\
\hline Khuzastan & 60 & 69 & 81 & 58 & 79 & 97 & 1.5 & 1.5 \\
\hline Kerman & 44 & 66 & 97 & 55 & 67 & 100 & 0 & 0 \\
\hline Kermanshah & 4 & 70 & 95 & 62 & 75 & 100 & 0 & 0 \\
\hline Sistan \& Baluchastan & 5 & 70 & 90 & 75 & 80 & 0 & 100 & 0 \\
\hline
\end{tabular}


Table 3. Antibiograms of $V$. cholerae isolates in Iran, 1999-2000

\begin{tabular}{|c|c|c|c|c|c|c|c|c|c|c|c|c|}
\hline \multirow[b]{2}{*}{ Province } & \multirow{2}{*}{$\begin{array}{c}\text { Number of } \\
\text { isolates }\end{array}$} & \multicolumn{10}{|c|}{ Antibiotic resistance (\%) } & \multirow{2}{*}{$\begin{array}{c}\text { Plasmids } \\
(\%)^{*}\end{array}$} \\
\hline & & $\mathrm{C}$ & CIP & DOX & $\mathrm{E}$ & OXT & SXT & $\mathrm{T}$ & GM & $\mathrm{F}$ & $\mathrm{S}$ & \\
\hline Tehran & 58 & 0 & 0 & 0 & 0 & 100 & 100 & 0 & 0 & 100 & 100 & 96 \\
\hline Kashan & 29 & 0 & 0 & 0 & 100 & 0 & 0 & 0 & 0 & 0 & 100 & 62 \\
\hline Khuzastan & 60 & 1.6 & 0 & 0 & 0 & 95 & 97 & 27 & 0 & 34 & 100 & 52 \\
\hline Kerman & 44 & 2.4 & 0 & 4.8 & 2.4 & 2.4 & 100 & 4.8 & 0 & 100 & 100 & 75 \\
\hline Kermanshah & 4 & 0 & 0 & 0 & 0 & 100 & 100 & 0 & 0 & 100 & 100 & 33 \\
\hline Sistan \& Baluchastan & 5 & 0 & 0 & 0 & 0 & 0 & 100 & 0 & 0 & 100 & 100 & 50 \\
\hline
\end{tabular}

C, chloramphenicol; Cip, ciprofloxacin; Dox, doxycycline; E, erythromycin; Oxy, oxytetracycline; SXT, trimethoprim/sulphamethoxazole; T, tetracycline; GM, gentamicin; F, furazolidone, S, streptomycin.

${ }^{*}$ Percentage of $V$. cholerae isolates that contain plasmids.



Fig. 1. Ribotype analysis of $V$. cholerae DNA digested with $B g l$ I restriction endonuclease. Numbers on the left indicate the molecular size of the bands of Citrobacter koseri strain DNA (CIP 105177) cleaved with MluI (mol. wt marker, M). Lane 1, representative of non-O1, non-O139 V. cholerae isolates; 2-4, representatives of $V$. cholerae $\mathrm{O} 1$ isolates. 
seven bands, ranging from 13.0 to $4.5 \mathrm{~kb}$. Lane 4 was also a ribotype pattern of $V$. cholerae $\mathrm{O} 1$, with bands similar to lane 3 but with a difference at the lower part of the gel, which showed two bands with molecular sizes of 4.5 and $4.7 \mathrm{~kb}$. This pattern constituted $7 \%$ of the total $V$. cholerae $\mathrm{O} 1$ isolates.

Fig. 2 shows the representatives of NotI-digested PFGE patterns of $V$. cholerae isolates from Iran. PFGE analysis distinguished 10 different patterns amongst the isolates. Pattern 1 is representative of the non-O1, non-O139 isolates and the rest of the lanes are representative of $V$. cholerae $\mathrm{O} 1$ isolates.

\section{Discussion}

Most $V$. cholerae $\mathrm{O} 1$ isolates from different provinces in Iran were characterised by resistance to multiple antibiotics. The Iranian isolates can be grouped on the basis of their antibiotic resistance patterns into the following categories: (1) SxtFS, isolates resistant to sulphamethoxazole/trimethoprim (Sxt), furazolidone (F) and streptomycin (S); (2) SxtFSO, isolates with additional resistance to oxytetracycline (O); and (3) ES,
non-O1, non-O139 $V$. cholerae isolates resistant to erythromycin (E) and streptomycin (S) only.

Mukhopadhyay et al. [24] reported the resistance pattern SxtFACN (A, ampicillin; C, chloramphenicol; $\mathrm{N}$, nalidixic acid) in isolates from the Indian subcontinent. $V$. cholerae $\mathrm{O} 1$ isolates from Africa have been reported with the resistance pattern SxtSAPT (P, penicillin; T, tetracycline) $[25,26]$. In all, $81 \%$ of $V$. cholerae isolates in the present study showed the biochemical reactions of $V$. cholerae O1 biotype El Tor of the seventh pandemic, but their antibiotic susceptibility patterns differed in some respects from a number of the published reports $[24,27,28]$. Although no $V$. cholerae $\mathrm{O} 139$ isolates were obtained in this study, the resistance pattern of isolates studied here was similar to the antibiotic resistance in $V$. cholerae O139 carrying a conjugative transposon encoding for resistance to SxtS, as reported by Waldor et al. [29]. The reasons for this variation in antibiotic susceptibility patterns between different provinces are unclear. However, $V$. cholerae $\mathrm{O} 1$ strains isolated after the $\mathrm{O} 139$ epidemic in India have shown increased resistance to various drugs and genotypes that were distinct from $\mathrm{O} 1$ strains isolated before and during the O139 epidemic [22],

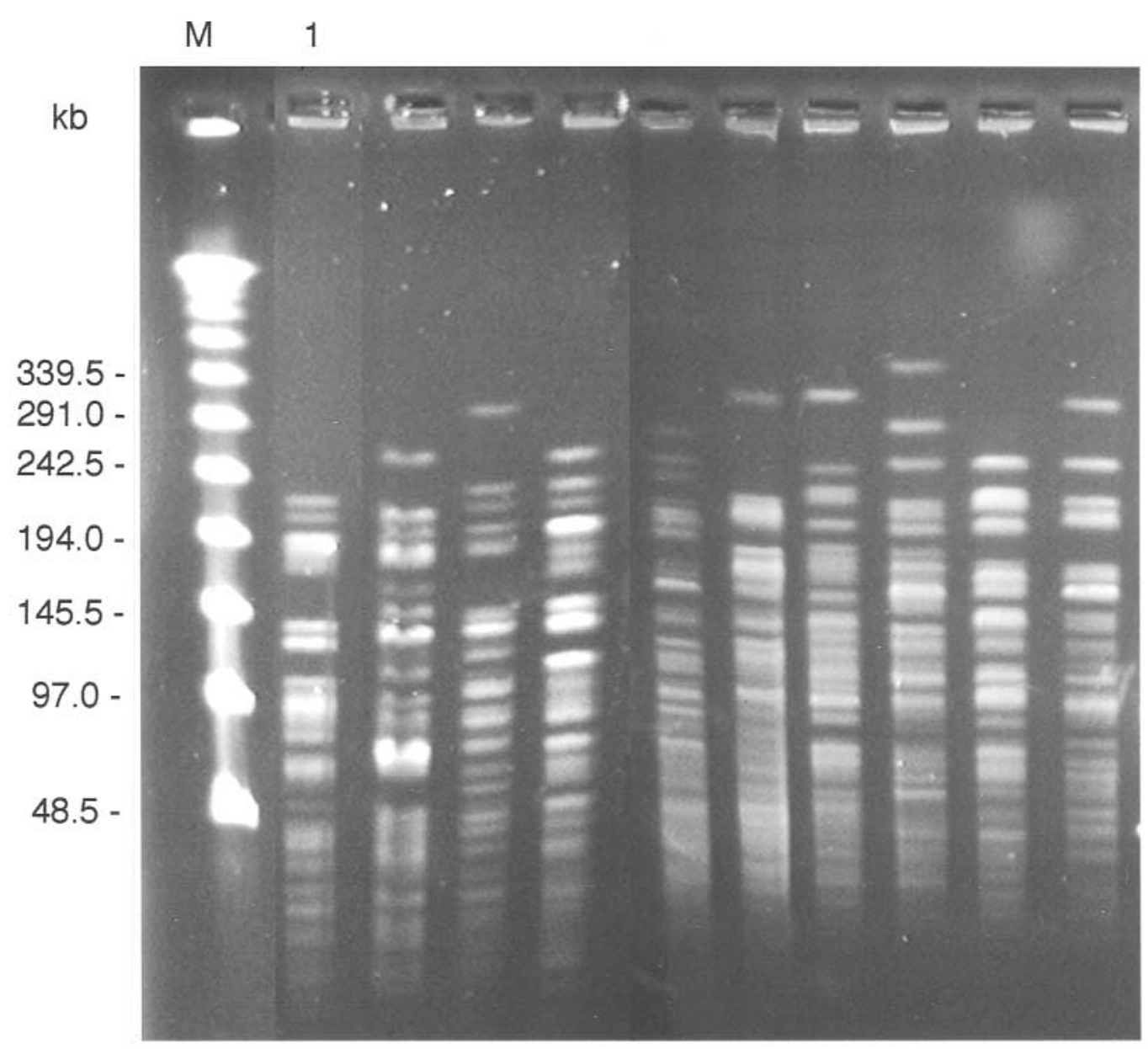

Fig. 2. PFGE fragment patterns of NotI-digested total cellular DNAs from $V$. cholerae non-O1, non-O139 (lane 1) and O1 (other lanes) isolates from different provinces in Iran. Size markers ( $\lambda$ ladder) were loaded in lane $\mathbf{M}$. The values are indicated in $\mathrm{kb}$ on the left side of the gel. 
suggesting that continuous genetic re-assortment amongst $V$. cholerae strains is taking place. Overall, several reports have indicated the re-appearance of distinct $V$. cholerae $\mathrm{O} 1$ and non-O1 strains in Asia, indicating the importance of genetic monitoring of emerging strains of this organism.

$V$. cholerae isolates in Iran were characterised by multiple antibiotic resistance coded by a specific plasmid. This observation is in accordance with other reports of the presence of the large plasmid in $V$. cholerae $\mathrm{O} 1$ and non-O1 strains $[5,30]$. The naturally conjugative plasmid of $100 \mathrm{~kb}$ was found in $61 \%$ of the isolates of $V$. cholerae $\mathrm{O} 1$ from different provinces, suggesting that this plasmid may not have a stable genetic character to remain autonomously in $V$. cholerae species in the cholera outbreaks. Furthermore, the study of co-transfer in the absence of detectable plasmids of SxtS resistance from a $V$. cholerae donor to an E. coli recipient provided evidence that the multiple antibiotic-resistant plasmid in the Iranian isolates may be located on a conjugative transposon.

Other investigators $[30,31]$ have reported the presence of the $c t x$ gene in clinical isolates of $V$. cholerae $\mathrm{O} 1$. On the other hand, the present study found variable results in PCR analysis of virulence cassette genes in 200 isolates of $V$. cholerae. The differences between the highest and lowest positive PCR-amplified genes in isolates of $V$. cholerae $\mathrm{O} 1$ were $8 \%, 16 \%, 23 \%$ and $25 \%$ for $t c p, c t x$, ace and zot genes, respectively. The lower percentage of toxin genes in some provinces in Iran may reflect the deletion of a toxin gene in the virulence cassette of the isolated strains [20,32, 33]. Although the re-arrangement and copy number of the virulence cassette may play an important role in determining the pathogenicity level of the isolates [34], the presence of a virulence cassette could be variable, as it is subjected to amplification and deletion under the control of the recA gene [34]. Moreover, the data obtained in the present study were also in accordance with other reports [35-37], i.e., V. cholerae non-O1, non-O139 strains rarely harbour cholera toxin genes or other virulence genes contained in the virulence cassette found in $\mathrm{O} 1$ and $\mathrm{O} 139$.

The high discriminatory power of PFGE and ribotyping has been used extensively in epidemiological investigations. PFGE and ribotyping of $V$. cholerae $\mathrm{O} 1$ isolates from Bangladesh and India have demonstrated that the O1 serotype, which re-appeared after being temporarily displaced by $V$. cholerae 0139, may represent a new clone $[4,38,39]$. The suggestion has been made $[36,40]$ that the new $V$. cholerae ribotype found in India, Bangladesh and Guinea-Bissau could be the cause of new epidemics. Ribotyping with the Bgll restriction endonuclease produced four distinct patterns amongst the $V$. cholerae isolates in this study, three of which were in serotype $\mathrm{O} 1$ isolates, and the fourth in non-O1, non-O139 isolates. Ribotype pattern 1 was a representative of non-O1, non-O139 V. cholerae isolates in Iran, which was similar to that reported by Dalsgaard et al. [36] in Thailand. Pattern 2 was recognised as $V$. cholerae $\mathrm{O} 1$ ribotype $\mathrm{B} 15$ in our database. Ribotype 3, known as B21, was a representative of an $\mathrm{O} 1$ strain that was found to be the predominant pattern for $V$. cholerae $\mathrm{O} 1$ isolated here. A similar pattern has also been reported in isolates from Thailand [5], referred to as type R1, and from isolates in Turkey, Romania and Lebanon [41]. Ribotype pattern 4 has been designated as type R3 by investigators of isolates from Vietnam, India, Thailand and Bangladesh [36, 42].

The results of PFGE have also demonstrated nine and one genotypes for $V$. cholerae $\mathrm{O} 1$ and non-O1, non-139 isolates, respectively, indicating greater biodiversity in isolates of serotype O1. Only one pattern was observed in ribotype and PFGE analysis of non-O1, non-O139 strains, which may be attributable to the fact that the isolates were obtained from an endemic situation.

In summary, these results show that new clones of $V$. cholerae, not found in a previous study [18], have spread in Iran. Furthermore, the data support the genetic diversity of $V$. cholerae in Iran, where this bacterium continues to be an important cause of diarrhoea.

This research was supported in part by the Reseau International des Instituts Pasteur et Associes, Institut Pasteur, Paris, France. Special thanks are due to Dr Saifi and Mrs Lutfie for performing plasmid conjugation experiments and antibiotic susceptibility testing.

\section{References}

1. Yamamato T, Nair GB, Albert MJ, Paradi CC, Takeda Y Survey of in vitro susceptibilities of Vibrio cholerae $\mathrm{O} 1$ and O139 to antimicrobial agents. Antimicrob Agents Chemother 1995; 39: 241-244.

2. Dalsgaard A, Skov MN, Serichantalergs O, Echeverria P, Meza $\mathrm{R}$, Taylor DN. Molecular evolution of Vibrio cholerae O1 strains isolated in Lima, Peru, from 1991 to 1995. J Clin Microbiol 1997; 35: 1151-1156.

3. Bag PK, Maiti S, Sharma C et al. Rapid spread of the new clone of Vibrio cholerae O1 biotype El Tor in cholera endemic areas in India. Epidemiol Infect 1998; 121: 245-251.

4. Yamasaki S, Nair GB, Bhattacharya SK, Yamamoto S, Kurazono H, Takeda Y. Cryptic appearance of a new clone of Vibrio cholerae serogroup O1 biotype El Tor in Calcutta, India. Microbiol Immunol 1997; 41: 1-6.

5. Dalsgaard A, Serichantalergs O, Forslund A, Pitarangsi C, Echeverria P. Phenotypic and molecular characterization of Vibrio cholerae $\mathrm{O} 1$ isolated in Samutsakorn, Thailand before, during and after the emergence of $V$. cholerae O139. Epidemiol Infect 1998; 121: 259-268.

6. Cholera Working Group, International Center for Diarrhoeal Diseases Research, Bangladesh. Large epidemic of cholera-like disease in Bangladesh caused by Vibrio cholerae 0139 synonym Bengal. Lancet 1993; 342: 387-390.

7. Chong-nguan M, Chaicumpa W, Moolasart $\mathrm{P}$ et al. Vibrio cholerae O139 Bengal in Bangkok. Lancet 1993; 342 430-431.

8. Sheikh A, Khan A, Malik T, Fisher-Hoch SP. Cholera in a developing megacity; Karachi, Pakistan. Epidemiol Infect 1997; 119: 287-292.

9. Bik EM, Bunschoten AE, Gouw RD, Mooi FR. Genesis of the novel epidemic Vibrio cholerae O139 strain: evidence for 
horizontal transfer of genes involved in polysaccharide synthesis. EMBO J 1995; 14: 209-216.

10. Farmer J, Hickman-Brenner F. The Prokaryotes. In: Balows AG, Dworkin M, Harder W, Schleifer K (eds) A handbook on the biology of bacteria: ecophysiology, isolation, identification, applications, 2nd edn. New York, Springer-Verlag. 1992: $2952-3011$.

11. Tison D. Vibrio. In: Murray PR, Baron EJ (eds) Manual of clinical microbiology. Washington, DC, ASM Press. 1999: 497-506.

12. Courvalin P, Goldstein F, Philippon A, Sirot J. L'antibiogramme; MP-VIDEOM. Paris. 1985.

13. Kado CI, Liu S-T. Rapid procedure for detection and isolation of large and small plasmids. J Bacteriol 1981; 145: $1365-$ 1373.

14. Iredell JR, Manning PA. Biotype-specific tcpA genes in Vibrio cholerae. FEMS Microbiol Lett 1994; 121: 47-54.

15. Trucksis M, Galen JE, Michalski J, Fasano A, Kaper JB Accessory cholera enterotoxin (Ace), the third toxin of a Vibrio cholerae virulence cassette. Proc Natl Acad Sci USA 1993; 90: 5267-5271.

16. Fields PI, Popvic T, Wachsmuth K, Olsvik Ø. Use of polymerase chain reaction for detection of toxigenic Vibrio cholerae O1 strains from Latin American cholera epidemic. $J$ Clin Microbiol 1992; 30: 2118-2121.

17. Tamayo M, Koblavi S, Grimont F, Castaneda E, Grimont PAD. Molecular epidemiology of Vibrio cholerae O1 isolates from Columbia. J Med Microbiol 1997; 46: 611-616.

18. Pourshafie MR, Grimont F, Saifi M, Grimont PAD. Molecular epidemiological study of Vibrio cholerae isolates from infected patients in Teheran, Iran. $J$ Med Microbiol 2000; 49: 10851090.

19. Regnault B, Grimont F, Grimont PAD. Universal ribotyping method using a chemically labelled oligonucleotide probe mixture. Res Microbiol 1997; 148: 649-659.

20. Damian M, Koblavi S, Carle I et al. Molecular characterization of Vibrio cholerae $\mathrm{O} 1$ strains isolated in Romania. Res Microbiol 1998; 149: 745-755.

21. Machado J, Grimont F, Grimont PAD. Computer identification of Escherichia coli rRNA gene restriction patterns. Res Microbiol 1998; 149: 119-135.

22. Sharma C, Ghosh A, Dalsgaard A et al. Molecular evidence that a distinct Vibrio cholerae O1 biotype El Tor strain in Calcutta may have spread to the African continent. $J$ Clin Microbiol 1998; 36: 843-844.

23. Arakawa E, Murase T, Matsushita $\mathrm{S}$ et al. Pulsed-field gel electrophoresis-based comparison of Vibrio cholerae $\mathrm{O} 1$ isolates from domestic and imported cases of cholera in Japan. $J$ Clin Microbiol 2000; 38: 424-426.

24. Mukhopadhyay AK, Garg S, Nair GB. Biotype traits and antibiotic susceptibility of Vibrio cholerae serogroup $\mathrm{O} 1$ before, during and after the emergence of the O139 serogroup. Epidemiol Infect 1995; 115: 427-434.

25. Olukoya DK, Ogunjimi AA, Abaelu AM. Plasmid profiles and antimicrobial susceptibility patterns of Vibrio cholerae $\mathrm{O} 1$ strain isolated during a recent outbreak in Nigeria. J Diarrhoeal Dis Res 1995; 13: 118-121.

26. Coppo A, Colombo M, Pazzani C et al. Vibrio cholerae in the horn of Africa: epidemiology, plasmids, tetracycline resistance gene amplification and comparison between $\mathrm{O} 1$ and non-O1 strains. Am J Trop Med Hyg 1995; 53: 351-359.
27. Clark CG, Kravetz AN, Alekseenko VV, Krendelev YUD, Johnson WM. Microbiological and epidemiological investigation of cholera epidemic in Ukraine during 1994 and 1995 Epidemiol Infect 1998; 121: 1-13.

28. Kruse H, Sørum H, Tenover F, Olsvik Ø. A transferable multiple drug resistance plasmid from Vibrio cholerae $\mathrm{O} 1$. Microb Drug Rest 1995; 1: 203-210.

29. Waldor MK, Tschäpe H, Mekalanos JJ. A new type of conjugative transposon encodes resistance to sulfamethoxazole, trimethoprim, and streptomycin in Vibrio cholerae 0139 $J$ Bacteriol 1996; 178: 4157-4165.

30. Radu S, Ho YK, Lihan S et al. Molecular characterization of Vibrio cholerae $\mathrm{O} 1$ and non-O1 from human and environmental sources in Malaysia. Epidemiol Infect 1999; 123: $225-232$.

31. Minami A, Hasimoto $\mathrm{S}$, Abe $\mathrm{H}$ et al. Cholera enterotoxin production in Vibrio cholerae O1 strains isolated from the environment and from humans in Japan. Appl Environ Microbiol 1991; 57: 2152-2157.

32. Kurazono H, Pal A, Bag PK et al. Distribution of genes encoding cholera toxin, zonula occludens toxin, accessory cholera toxin, and El Tor hemolysin in Vibrio cholerae of diverse origins. Microb Pathog 1995; 18: 231-235.

33. Wachsmuth IK, Evins GM, Fields PI et al. The molecular epidemiology of cholera in Latin America. J Infect Dis 1993; 167: $621-626$

34. Mekalanos JJ. Duplication and amplification of toxin genes in Vibrio cholerae. Cell 1983; 35: 253-263.

35. Morris J. Vibrio cholerae and cholera. In: Wachsmuth I, Blake $\mathrm{P}$, Ølsvik O (eds) Molecular to global perspective. Washington, DC, ASM Press. 1994: 103-115.

36. Dalsgaard A, Forslund A, Bodhidatta L et al. A high proportion of Vibrio cholerae strains isolated from children with diarrhoea in Bangkok, Thailand are multiple antibiotic resistant and belong to heterogenous non-O1, non-O139 Oserotypes. Epidemiol Infect 1999; 122: 217-226.

37. Sharma C, Thungapathra M, Ghosh A et al. Molecular analysis of non-O1, non-O139 Vibrio cholerae associated with an unusual upsurge in the incidence of cholera-like disease in Calcutta, India. J Clin Microbiol 1998; 36: 756-763.

38. Faruque SM, Ahmed KM, Alim ARMA, Qadri F, Siddique AK, Albert MJ. Emergence of a new clone of toxigenic Vibrio cholerae $\mathrm{O} 1$ biotype El Tor displacing V. cholerae O139 Bengal in Bangladesh. J Clin Microbiol 1997; 35: 624-630.

39. Faruque SM, Ahmed KM, Siddique A, Zaman K, Alim ARMA, Albert MJ. Molecular analysis of toxigenic Vibrio cholerae 0139 Bengal strains isolated in Bangladesh between 1993 ad 1996: evidence for emergence of a new clone of the Bengal vibrios. J Clin Microbiol 1997; 35: 2299-2306.

40. Dalsgaard A, Mortensen HF, Mølbak K, Dias F, Serichantalergs O, Echeverria P. Molecular characterization of Vibrio cholerae O1 strains isolated during cholera outbreaks in Guinea-Bissau. J Clin Microbiol 1996; 34: 1189-1192.

41. Koblavi S. Identification et typage moleculaire des Vibrionaceae; Paris VII University, France, 1996.

42. Dalgsaard A, Forslund A, Tam NV, Vinh DX, Cam PD. Cholera in Vietnam: changes in genotypes and emergence of class I integrons containing aminoglycoside resistance gene cassettes in Vibrio cholerae O1 strains isolated from 1979 to 1996. J Clin Microbiol 1999; 37: 734-741. 